\title{
Quasi-Markets and Service Delivery Flexibility Following a Decade of Employment Assistance Reform in Australia
}

\author{
MARK CONSIDINE, JENNY M. LEWIS and SIOBHAN O'SULLIVAN
}

Accepted for publication in Journal of Social Policy (Cambridge, 2011)

\begin{abstract}
In 1998, we were witnessing major changes in frontline social service delivery across the OECD and this was theorised as the emergence of a post-Fordist welfare state. Changes in public management thinking, known as New Public Management (NPM), informed this shift, as did public choice theory. A 1998 study of Australia's then partially privatised employment assistance sector provided an ideal place to test the impact of such changes upon actual service delivery. The study concluded that frontline staff behaviour did not meet all the expectations of a post-Fordist welfare state and NPM, although some signs of specialisation, flexibility and networking were certainly evident (Considine, 1999). Ten years on, in 2008, frontline staff working in Australia's now fully privatised employment sector participated in a repeat study. These survey data showed convergent behaviour on the part of the different types of employment agencies and evidence that flexibility had decreased. In fact, in the ten years between the two studies there was a marked increase in the level of routinisation and standardisation on the frontline. This suggests that the sector did not achieve the enhanced levels of flexibility so often identified as a desirable outcome of reform. Rather, agencies adopted more conservative practices over time in response to more detailed external regulation and more exacting internal business methods.
\end{abstract}

\section{Introduction - early expectations of the post-Fordist welfare state}

A decade ago, there was a widely held view that the 'world of large, hierarchically defined public organisations which provide their citizens with a set menu of standard, universal services, delivered by a career workforce, is nearing the end of its time of social and political dominance' (Considine, 1999: 183-4). ${ }^{1}$ In the late 1990s, a consensus had not yet developed 
concerning what would replace this traditional bureaucratic public service model (Williamson, 1975; Rogers and Larsen, 1984), but a number of likely features of the new system were beginning to emerge. Specifically, it was anticipated that '[o]rganisations will continue to be the primary locus of social and political decision making and play a central role in the delivery of programmes. However they [will] become smaller, . . .more numerous, and relate to one another through both bureaucratic and non-bureaucratic forms of coordination' (Considine, 1999: 184; for further information see Drucker, 1985; Powell, 1990; Hoggett, 1987). Associated with this structural shift, there were signs that pressure was already being applied to public service staff to adopt the types of flexible work patterns commonly associated with the private sector. At the same time, increased levels of diversity within the community were resulting in calls for more varied forms of welfare provision (Considine, 1999: 184; Lash and Urry, 1987).

At this time, it was hypothesised that the post-Fordist welfare state was likely to develop the following core attributes: the de-coupling of programmes from traditional forms of bureaucratic hierarchy, decentralisation of key resource allocations, contracting out of major programme activities, competition between programme providers, use of client-centred techniques of co-ordination and enrolment of clients and their support network into coproduced services. These changes would necessitate the evolution of new regulatory structures to allow governments to maintain control over service delivery systems in the face of self- organising policy networks designed to harness entrepreneurial behaviour and permit greater discretion in how clients are treated.

It was this tension between the pursuit of innovation through the use of non-bureaucratised structures on the one hand, and the state's role in directing and ensuring the delivery of basic welfare services on the other, that informed the design and delivery of the 1998 study. The results showed that the operation of Australia's partially out-sourced employment system met some of the expectations of the new post-Fordist welfare state. For example, there was an increase in the number of service providers delivering employment services in Australia, and they did so as small operational units. Moreover, private agencies performed in some ways that were consistent with flexible, entrepreneurial workplaces, such as providing more individualised services. However, the new forms of service networking or flexible specialisation had not eventuated as forecast. Indeed, the 1998 data showed that many new 
agencies were replicating a similar menu of services over and over again, instead of behaving in entrepreneurial ways, as had been anticipated (Considine, 1999: 191).

This paper aims to examine changes in the delivery of employment services on the frontline over the last decade. Has the system become more decentralised, flexible, client-focused and co-produced? Or has it become more regulated or even standardised since the introduction of system changes a decade ago? We consider in particular the impact of risk-management and audit imperatives associated with the operations of a contracted system and following the work of Power (1997) and Hood et al. (2001), we suggest that certain 'regime' characteristics help explain a certain kind of dynamic disappointment in the delivery of reform in this case. In the next section, the research design is outlined, followed by an explanation of changes to Australia's employment system over the last ten years. Results from the key 2008 survey data are then presented and discussed.

\section{Research design}

In Australia, basic job-search assistance is provided to all unemployed citizens and is compulsory for those receiving income support. Services range from job matching through to training and intensive support, such as counselling and motivational support. The data presented here are drawn from a survey of frontline employment services staff operating in various contracted agencies and public service institutions in Australia, the United Kingdom, the Netherlands and New Zealand. ${ }^{2}$ The survey was conducted for the first time between 1996 and 1999 (referred to here as the 1998 survey) and for a second time in 2008 . $^{3}$ This paper considers the Australian data only. For the purposes of this research, frontline staff are defined as staff who work directly with jobseekers to help them become job-ready, or to assist them either secure, or retain, employment. For the 2008 survey, we sought responses from staff delivering Job Network services. Job Network was Australia's employment assistance program. It ran from 1998 until June 2009. Job Network did not service jobseekers classified as disabled, or those in need of special assistance.

The 1998 survey was completed by 625 Australian frontline employment services staff. At that time Australia had a partially contracted-out employment system, meaning survey participants worked for one of three types of employment agency: public service, private not- 
for-profit or private for-profit. The 1998 survey was paper-based. The response rate for the first survey was 56 per cent in total. ${ }^{4}$ See Table 1 for the sample distribution.

The 2008 survey was designed to be as similar to the 1998 version as possible, although it was updated to reflect changes in nomenclature and industry practice. By 2008, all Australian employment services were delivered by private contracted providers, meaning survey participants worked for either a private not-for-profit or a private for-profit employment services agency. This second survey was completed online, and in Australia the response rate was 44 per cent. Thirty-four Australian employment services agencies participated in the 2008 survey and 1,512 frontline staff completed the questionnaire (see Table 1).

Table 1. Distribution of responses by survey period and agency type

\begin{tabular}{|l|l|l|l|l|l|}
\hline & Government & $\begin{array}{l}\text { For-profit } \\
\text { agency }\end{array}$ & $\begin{array}{l}\text { Not-for- } \\
\text { profit agency }\end{array}$ & $\begin{array}{l}\text { Agency } \\
\text { unknown }\end{array}$ & Total \\
\hline 1998 & 271 & 118 & 196 & 38 & 625 \\
\hline 2008 & 0 & 392 & 1056 & 64 & 1512 \\
\hline Total & 273 & 501 & 1252 & 102 & 2137 \\
\hline
\end{tabular}

The survey instrument was comprised of around 100 questions designed to elicit information about how frontline staff carry out the basic service delivery tasks required in assisting jobseekers find work, including whether they use standardised assessment tools; scripted, information technology (IT)-driven driven interview techniques; or exercise discretion about the types of activities they negotiate with clients. Only a small number of the questions asked in the survey are discussed here. The questions selected are those that deal most directly with the degree of flexibility, standardisation and routinisation.

The first survey was developed following a series of exploratory interviews with Australian frontline employment services staff conducted in the mid-1990s. Once the 2008 survey data were collected, the research team undertook a second round of in-depth interviews with frontline employment services professionals. Fourteen interviews were conducted with staff from six different employment agencies, chosen on the basis of long-service in the sector. Interviews were used to elicit interpretations and explanations for the changes that had taken place, and were undertaken between November 2009 and February 2010. 
The survey data were analysed using SPSS statistical software. For the sake of analytical consistency, all data were assumed to be non-parametric. The Chi- Squared Test was used to test for statistical significance between survey years, and between different types of agencies, for all associations with categorical variables. The Mann-Whitney U or the Kruskal-Wallis Test was used for all questions where the response was numeric. Statistical significance was tested for at the 0.05 level, although precise p-values are provided where appropriate.

\section{Policy developments in the Australian employment sector}

Australia has a federal political system with power shared between the Federal, or Australian, Government, and the six states and two territories that make up the Commonwealth of Australia. The bulk of Australian social services are delivered by state or territory governments. However, the history of Australian federalism is one in which power has steadily shifted away from the states towards the federal government, the result being that the Australian Federal Government is highly engaged in funding and administrating many core social services, including the delivery of employment assistance. In more recent times, the two sides of Australian politics have found common ground in regard to so-called New Public Management (NPM) reforms designed to promote increased public sector efficiency, including through forms of privatisation. As such, it was Labor Prime Minister Paul Keating, who held office from 1991 until 1996, who initiated the reform of Australia's employment system. In a 1994 White Paper, Keating outlined a new, competitive, client focused employment system where:

The emphasis will move away from processing large numbers of jobseekers through relatively rigid national programs. The key elements of the new strategy are an accurate assessment of the needs of jobseekers and an intensive plan to assist disadvantaged people. (Keating, 1994: 127)

In Prime Minister Keating's view that required a shift away from the public delivery of employment services and a move towards the private sector with its penchant for flexible, market-driven solutions. In the White Paper, Keating asserted that '[h]ealthy competition will lead to service improvement' (Keating, 1994: 127). 
The first wave of reform occurred under Labor between 1994 and 1996. It involved such initiatives as the introduction of private employment service providers; individual case management for long-term unemployed; the ability, on behalf of the job seeker, to choose his/her own employment agency and negotiate a service contract; the introduction of government funded training programs available to those who had been unemployed for over eighteen months; payment to private providers on a fee-for-success basis; and competition between providers based on the quality of their performance (Finn, 1997; Considine, 2005: 43). Under the new model around two-thirds of Australia's employment services moved from a public service to a mix of private sector and not- for-profit agencies. In the early stages of privatisation, the public service was not required to bid for contracts in competition with private employment agencies.

The Howard Coalition Government won office in 1996 and held it until 2007. It began its restructuring of the Australian employment sector quickly after forming government. The first round of Howard-era reforms focused on abolishing many of the training programs initiated by the Keating Government. The Howard Government closed the remaining public agencies and distributed contracts among private for-profit and not-for-profit agencies. The government also substantially changed the way the sector was regulated. At that time, Centrelink was created as a new arms-length public agency tasked with managing all social security payments as well as the provision of a limited public component of employment services. In practice, this meant that 'basic' employment services were delivered by Centrelink and 'elaborated services' came courtesy of the for-profit and not-for-profit agencies (Considine, 2005: 41-67). Australia's new employment system was called 'Job Network'. 5

The first Job Network contracts ran from May 1998 until February 2000. The second contracts were operational from February 2000 until June 2003. In 2002, the Government announced that the third Job Network contracts would be for 40 per cent of the contracts only and the remaining 60 per cent market share were 'rolled-over' into new contracts for existing agencies. Under this system, agencies were selected for an extended contract based on their prior performance. The third contract commenced in mid-2003 and it ushered in a system whereby all jobseekers were referred to a private employment agency for customised assistance. This was unlike earlier iterations where only certain categories of unemployed people were streamed through the contracted service providers (Considine, 2005: 41-67). 
Between 2003 and 2008, there was no comprehensive tendering process for Job Network. Instead small sections of the market went to tender, while some pre-existing contracts were extended. The need to quantify each agency's performance, for the purpose of offering extended contracts, was one of the drivers behind the development of the 'Star Ratings' system. Star Ratings are an audit and assessment issued twice annually by the purchaser to every employment services office in Australia. The grade is between zero and five, increasing in half point increments. It is calculated using a regression model which includes variables for local labour market conditions and characteristics of job seekers and a range of performance outcome measures such as the numbers who exit the benefit rolls, the speed with which they exit and the duration of subsequent employment (Access Economics and the Department of Employment and Workplace Relations, 2002: 8). The Star Rating system was launched in $1999 .^{6}$

Prime Minister John Howard lost office in December 2007. By that time, comprehensive outsourcing of these public services was a standard part of the employment sector in many OECD countries. ${ }^{7}$ However, the Australian system was unique because, by the end of the Howard era, all Australian jobseekers in receipt of a government payment were assigned to an agent employed by a for-profit or not-for-profit employment services provider. In the next section, data collected at the start of Howard's term is compared to data collected within eight months of his Government's defeat. The analysis which follows examines the cumulative impact of the changes studied in 1998, together with the impact of subsequent changes in government policy. This comparison provides the first in-depth study of the way social services are affected by the comprehensive shift to contracting-out and quasi-markets, the key instruments of NPM. It enables a reasonable test of such impacts and an opportunity to observe long-range trends in the provision of welfare services.

\section{Control at the frontline}

The contracting-out of formerly public services is based upon the idea that the market (or quasi-market) can deliver more efficient and more flexible tailored services than can large public bureaucracies. ${ }^{8}$ The rationale and justification behind the semi- and subsequent fullprivatisation of Australia's employment system is closely aligned with those principles. For 
example, a discussion paper released by the Howard Government in 2002 asserted that 'Job Network is delivering more diversity, innovation and choice at almost seven-times the number of locations of its predecessor, the Commonwealth Employment Service [CES]' (Commonwealth of Australia, 2002: 4). A draft code of conduct for providers, contained in the same document, also required them to pledge to deliver accurate and relevant services by 'tailoring assistance to meet clients' needs', '[and by] being flexible in service delivery as clients' circumstances change' (Commonwealth of Australia, 2002: 26). Both these claims suggest the government considered private provision through competitive tendering as a means of increasing flexibility at the point of service delivery. Greg Marston and Catherine McDonald (2007: 237) interpret the privatisation process in a similar light when they argue that ' $[\mathrm{t}]$ he competitive model was introduced [in Australia] in the belief there would be efficiencies in budgetary terms and greater efficiencies in service delivery outcomes', while Thomas Bredgaard and Flemming Larsen (2008: 343) talk of the 'explicitly politically formulated arguments to create a more efficient and un-bureaucratic system [in Australia, the Netherlands and Denmark]'.

An innovative, flexible approach to service delivery was therefore one of the things tested in both the 1998 and 2008 studies. After observation and in-depth interviews at a variety of local sites, a series of questions about typical work practices to elicit information about the way staff interact with jobseekers were developed. Frontline staff were asked to respond to a series of statements about discretion, autonomy and use of standardised tools in their day-today work. The actual wording of these statements can be found in Table 2. In a service where most of the transactions involve face-to-face interviews and choices about where clients should be referred, these questions provide key insights into the level and extent of standardisation and the scope for 'tailoring'. The hypothesis driving this approach was that, in a traditional bureaucratic service, the role of frontline staff is to apply standard rules of eligibility to clients using pre-determined classifications in order to assign them to common pathways for receipt of benefits and services. Where services use the 'tailoring' approach, frontline staff are expected to exercise a high level of discretion, both in getting to the heart of the client's circumstances and in shaping an agenda of action (Considine, 1999: 186; Kemp, 1981: 10; Hammond, 1997: 34). 
Table 2: Entrepreneurialism in the workplace

\begin{tabular}{|c|c|c|c|c|c|}
\hline & $\begin{array}{l}\text { Strongly } \\
\text { agree }\end{array}$ & Agree & Neither & Disagree & $\begin{array}{l}\text { Strongly } \\
\text { disagree }\end{array}$ \\
\hline \multicolumn{6}{|c|}{$\begin{array}{l}\text { 'When it comes to day-to-day work, I am free to decide for myself what I will do with each } \\
\text { jobseeker.' }\end{array}$} \\
\hline 1998 & $164(27.1 \%)$ & $348(57.5 \%)$ & $50(8.3 \%)$ & $40(6.6 \%)$ & $3(0.5 \%)$ \\
\hline 2008 & $165(18.4 \%)$ & $396(44.1 \%)$ & $133(14.8 \%)$ & $165(18.4 \%)$ & $38(4.2 \%)$ \\
\hline \multicolumn{6}{|c|}{ (Chi-squared $=93.61 ; p<0.001)$} \\
\hline \multicolumn{6}{|c|}{ 'My supervisor knows a lot about the work I do day-to-day. } \\
\hline 1998 & $67(11.0 \%)$ & $276(45.2 \%)$ & $69(11.3 \%)$ & $140(23.0 \%)$ & $58(9.5 \%)$ \\
\hline 2008 & $296(33.3 \%)$ & $430(48.4 \%)$ & $69(7.8 \%)$ & $60(6.8 \%)$ & $33(3.7 \%)$ \\
\hline \multicolumn{6}{|c|}{ (Chi-squared $=0.0171 ; \mathrm{p}<0.001)$} \\
\hline \multicolumn{6}{|c|}{$\begin{array}{l}\text { 'When I come across something not covered by the procedural guide, I refer it to my } \\
\text { supervisor.' }\end{array}$} \\
\hline 1998 & $69(11.3 \%)$ & $275(45.4 \%)$ & $89(14.6 \%)$ & $127(20.9 \%)$ & $48(7.9 \%)$ \\
\hline 2008 & $306(34.5 \%)$ & $502(56.6 \%)$ & $47(5.3 \%)$ & $28(3.2 \%)$ & $4(0.5 \%)$ \\
\hline \multicolumn{6}{|c|}{ (Chi-squared $=0.0287 ; \mathrm{p}<0.001)$} \\
\hline \multicolumn{6}{|c|}{ 'Our computer system tells me what steps to take with jobseekers and when to take them.' } \\
\hline 1998 & $9(1.5 \%)$ & $95(15.9 \%)$ & $123(20.6 \%)$ & $261(43.7 \%)$ & $109(18.3 \%)$ \\
\hline 2008 & $45(5.1 \%)$ & $375(42.3 \%$ & $211(23.8 \%)$ & $204(23.0 \%)$ & $52(5.9 \%)$ \\
\hline
\end{tabular}

In 1998, frontline staff working in Australia's partially contracted-out, or privatised, employment sector did in fact demonstrate a high level of flexibility at the service level (Considine, 1999). Results from the survey showed that 84.6 per cent of those surveyed agreed, or strongly agreed, with the statement 'when it comes to day-to-day work I am free to decide for myself what I will do with each jobseeker'. However, by 2008, the proportion of frontline staff who either agreed, or strongly agreed, with that statement had fallen 22.1 percentage points to 62.5 per cent (see Table 2). That difference is statistically significant ( $\mathrm{p}$ $<0.001$ ) and suggests a large decline in frontline flexibility by 2008.

During the interviews conducted following the 2008 survey, this issue was raised with experienced staff members. 'Tony', who had worked for a not-for- profit agency since Job Network's inception represented a widely held view when he observed that ' $[\mathrm{w}] \mathrm{e}$ had far more flexibility [at the start of Job Network]'. He went on to explain that when Australian employment services were first privatised, the requirement to demonstrate why a particular 
activity was a suitable or legitimate job-search activity was not as onerous. He argued that by 2008 , 'they' $d$ [case managers] be accountable for that spend ${ }^{9}$ and they're very cautious because they've got to be accountable ... So that creativity probably isn't there today that was there six or seven years ago'. He also said that:

the pressure they're [case managers] under today is probably five to ten times greater than what we were under back then [at the start of Job Network]. That could be a sign of the times, I couldn't tell you the exact reasons, but part of that is that the complexity that the government has built into this contract now and the fear our frontline staff have of getting it wrong.

And:

[s]taff tend to now, rather than being creative, they're safe. So we know that solution was okay and approved by the Department [of Education, Employment and Workplace Relations] but whether that's the right solution, that's the one we'll use because it's safe. That's a really bad way to approach it because you're never going to get that uniqueness and the creativity in the industry.

Other interviewees reinforced this account. For example, 'Maxine', who had been working in a for-profit agency for nine and a half years observed that: 'the government just wasn't as ... as structured I suppose, I don't know if that's the word. But the parameters they put on us were a lot more flexible then [at the start of Job Network], than what they are now.' A similar account was given by 'Sonia', who had worked as a frontline staff member for fifteen years. She said: 'I think people are very concerned now of doing something wrong and being pulled up from that point of view, I think the rules in that sense have become much more stringent.'

There are clearly a number of things embedded in these comments. The agreed decline in discretion is associated in their minds with a fear of making wrong decisions and this in turn is associated with significant penalties. This echoes a stronger regulatory regime in Australia, which, over this period, increased the capacity of the purchaser to recover payments from contractors if it later proved that the exercise of discretion was not justified. With the move towards the 'roll-over' of contracts and the use of Star Ratings there was also an increase in the contestability of local allocations, making local practices more important to business 
viability than before. This could be explained both as an increase in the quality of surveillance by the purchaser and in the depth of monitoring and discipline of local services by their own head office.

Another way to explore whether the level of flexibility employment services staff exercised at the frontline decreased over the course of Job Network is to consider the relationship frontline staff had with their supervisors. A system which encourages tailoring of services to both employer and jobseeker is likely to be one in which staff have the capacity to act somewhat independently. The 1998 study showed that, although there was a trend towards flexibility at the frontline when services were first outsourced, innovation was also linked to supervisory oversight and strong leadership. The expression 'supervised flexibility' was used to describe this approach to service delivery, reflecting a workplace in which frontline staff had the knowledge and capacity to direct jobseekers and marshal local resources. These case managers, as they were called at the time, were a primary source of expertise in the agency and with that expertise went a degree of independence from supervision. At the time of the first survey, 11 per cent of survey respondents felt their supervisor 'knew a lot about the work they do day-to-day'. By 2008, that figure had tripled to 33.3 per cent. In 1998, 32.5 per cent of those surveyed disagreed or strongly disagreed with the statement. That figure had fallen to 10.5 per cent by the time of the second survey (see Table 2).

Another dimension of this independence was the extent to which frontline staff felt they could trust their own judgement, versus the practice of referring unfamiliar eventualities to someone more senior. Table 2 shows that while 11.3 per cent of those surveyed in 1998 strongly agreed that when they come across something not covered by the 'procedureal guide' they would refer it to their supervisor, that percentage increased to 34.5 by 2008 . The difference between the 1998 and 2008 results are statistically significant for both supervision related questions.

A further measure of flexibility at the frontline is linked to how frontline staff use their IT system. In this context, heavy reliance on IT driven systems is considered more likely to generate routinisation in service delivery. Of course, this is not always the case and IT systems can provide ways to increase local flexibility, for example, by increasing access to a wide menu of activities that clients can be directed to. So we examined the nature of these IT systems at the local level to ascertain that they were in fact based on system-wide 
requirements for structuring interactions with jobseekers, which limits frontline staff options and reduces discretion both to make mistakes and to create innovations. In response to the statement 'our computer system tells me what steps to take with jobseekers and when to take them', 17.4 per cent agreed or strongly agreed in 1998. By 2008, that figure had increased to 47.4 per cent (see Table 2$)$. That difference is statistically significant $(\mathrm{p}<0.001)$ and suggests reduced service delivery discretion.

In a follow-up question in the 2008 survey, staff were asked about the extent to which they felt the IT system (EA3000) dictates how they do their job. EA3000 provides an interface between the Department of Education, Employment and Workplace Relations (DEEWR), Centrelink and employment service providers. DEEWR is the government department responsible for contractual oversight in the employment sector. EA3000 is the primary means by which client data are shared between the three bodies, and it is also integral to the contract compliance requirements placed on employment service providers by the purchaser. Marston (2006: 84) argues that Job Network's operation is 'contingent' on 'a complex infrastructure for data sharing and performance monitoring between government and community [contracted] agencies' and that the advent of e-government reinforces the NPM agenda (Marston, 2006: 85).

Some 23 per cent of survey respondents indicated that EA3000 dictates how they do their job to a large extent. Just over a quarter selected the second strongest level of agreement (25.7 per cent), while 20.8 per cent opted for the third strongest (on a seven point scale). In total, 69.5 per cent of those surveyed felt that EA3000 dictates how they do their job, to a reasonable extent (see Table 3). Close to 70 per cent of Australian employment services staff reported that a computer program directs them in their job, suggesting that flexibility was not a prominent feature of Australian employment services by 2008. 
Table 3: Flexibility and IT (2008 only)

\begin{tabular}{|c|c|c|c|c|c|c|c|}
\hline & \multicolumn{4}{|c|}{ To a large extent } & \multicolumn{3}{|c|}{ To a small extent } \\
\hline 'The extent to which & 1 & 2 & 3 & 4 & 5 & 6 & 7 \\
\hline you feel the IT & 245 & 274 & 221 & 155 & 92 & 57 & 21 \\
\hline $\begin{array}{l}\text { system you use } \\
\text { (EA3000) dictates } \\
\text { how you do your } \\
\text { job.' }\end{array}$ & $(23.0 \%)$ & $(25.7 \%)$ & $(20.8 \%)$ & $(14.6 \%)$ & $(8.6 \%)$ & $(5.4 \%)$ & $(2.0 \%)$ \\
\hline
\end{tabular}

The issue of IT directed services was discussed by 'Tony' who recounted that:

Back when I delivered the service, I sat down at a desk with somebody. Sure, I might've had a piece of paper or something else, might've even had a computer, but it's usually on another desk and I sat with the person and talked through what we needed to do to get them a job. I dealt with that person, I dealt with those challenges. When I came back into the industry [after a 12 month break], every single consultant had a computer on their desk and they dealt with the computer, and the person on the other side was just an instrument to complete the compliance. It was almost as if we'd completely lost focus of actually dealing with the person and that there was a real person on the other side of the desk.

Similarly, 'Sonia' claimed that at the time Job Network was starting, the IT system was: '[n]ot half as important as it is now, not even quarter, you're ruled by IT at the moment'.

The use of client classification tools, or other structured assessment instruments, is designed to standardise the judgements being made about client needs. It replaces part of the skill set that a case manager might otherwise need. When asked about how assessment tools changed over the life of Job Network, 'Juan', who had been in the sector for twenty years, and who works for a for-profit employment agency, recalled that 'about five, six years ago we used a very quite basic form, a quick fast thing, but then I think later on they're changing it, so the form is getting longer, the form gets to be more detailed'. 
Not only are the forms getting longer, but their use is becoming more common. In 1998, 70.5 per cent of survey respondents said they did not use a standard client classification tool when deciding how to work with jobseekers. By 2008, that proportion had dropped to 15 per cent (see Table 4). This change is statistically significant $(\mathrm{p}<0.001)$. When asked about the tools used by frontline staff, 'Sonia' responded that:

the processes now in place have taken away maybe the ability to just deal with people a little bit . . . I think now there are so many, there is only so much leeway you've got now, there are so many rules involved that you really, it's become a much more administrative task I think now, almost like a process rather than an individual.

The use of a client classification pro-forma is intimately linked to more detailed control of the workplace by both the purchaser and the agency's head office. As a means of investigating a further dimension of this issue, survey participants were also asked how influential 'answers to a standard set of questions' are when deciding how to work with jobseekers. The results for that question also showed a shift in frontline practice over the ten-year period. In 1998, 49.6 per cent of surveyed frontline staff reported that standard questions were not influential at all. By 2008, only 7.8 per cent of survey respondents gave the same response (see Table 4). The difference between the 1998 and 2008 survey results is statistically significant (p < $0.001)$. 
Table 4: Use of standard classification and own judgement when working with jobseekers

\begin{tabular}{|l|l|l|}
\hline $\begin{array}{l}\text { 'Yes I use a standard client classification or checklist } \\
\text { when deciding how to work with jobseekers' }\end{array}$ & 1998 & 2008 \\
\hline $\begin{array}{l}\text { 'No I do not use a standard client classification or } \\
\text { checklist when deciding how to work with jobseekers' }\end{array}$ & $408(70.5 \%)$ & $746(79.8 \%)$ \\
\hline (Chi-squared = 0.0378; $\mathrm{p}<0.001)$ & & \\
\hline $\begin{array}{l}\text { 'Answers to a standard set of questions is } \\
\text { not influential at all' }\end{array}$ & $282(49.6 \%)$ & $90(7.8 \%)$ \\
\hline $\begin{array}{l}\text { 'Answers to a standard set of questions is } \\
\text { somewhat influential' }\end{array}$ & $164(28.8 \%)$ & $462(40.0 \%)$ \\
\hline $\begin{array}{l}\text { 'Answers to a standard set of questions is } \\
\text { quite influential' }\end{array}$ & $84(14.8 \%)$ & $395(34.2 \%)$ \\
\hline $\begin{array}{l}\text { 'Answers to a standard set of questions is } \\
\text { very influential' }\end{array}$ & $39(6.9 \%)$ & $208(18.0 \%)$ \\
\hline (Chi-squared = 0.0406; $\mathrm{p}<0.001)$ & $85(1.4 \%)$ & $21(1.8 \%)$ \\
\hline 'My own judgement is not influential at all' & $45(7.9 \%)$ & $290(25.1 \%)$ \\
\hline 'My own judgement is somewhat influential' & $204(35.7 \%)$ & $541(46.8 \%)$ \\
\hline 'My own judgement is quite influential' & $315(55.1 \%)$ & $304(26.3 \%)$ \\
\hline 'My own judgement is very influential' & & \\
\hline (Chi-squared = 0.0158; p < 0.001) & & \\
\hline
\end{tabular}

Another question investigated the extent to which discretion is being exercised at the frontline. Staff were asked how influential is your 'own judgement' when deciding how to work with jobseekers. At the negative end of the scale, 'not influential at all', there was very little change between 1998 and 2008 (see Table 4). ${ }^{10}$ At the time of the first survey, 1.4 per cent said their own judgement is not influential at all, whereas 1.8 per cent gave that response in 2008. However, at the other end, 'very influential', there was a marked shift between the two survey periods. In 1998, 55.1 per cent said that their own judgement were very influential. By 2008, that proportion had almost halved to 26.3 per cent. That difference is statistically significant $(\mathrm{p}<0.001)$.

Tables 2, 3 and 4 combined demonstrate that Australia's employment sector went from being relatively hierarchical, yet also flexible, at the start of Job Network, to a system in which frontline activities were more controlled and scripted. Job Network evolved into a far more regulated environment for both frontline staff and jobseekers. This runs counter to the expectation that contracting-out will increase agency flexibility and encourage greater 
tailoring. In the next section, we consider whether these findings hold true across all agencies, or whether certain types of agencies were better able to nurture flexibility among their frontline staff.

\section{Standardisation across the employment sector}

At the time of the 1998 survey, the Australian employment sector was a diverse 'quasi' marketplace. This involved the delivery of obligatory public services through privately run organisations. In 1999, Australia had 223 employment agencies, of various sizes and ownership types, delivering these frontline employment services.

At the time of the first survey, there was a significant difference between the responses from different types of agencies. At that time, government providers were still involved in delivering services and public servants registered comparatively high levels of supervision (Considine, 1999). There was also a variation between the extent to which frontline staff, working for different types of agencies, exercised discretion in how they worked with jobseekers. Moreover, organisations varied in the extent to which standard formulae were used, with for-profit frontline staff the most likely to consider their own judgement to be very important when deciding how to work with jobseekers (Considine, 1999). This suggested that contracting-out to private firms did increase flexibility in delivery. Other variations between agencies, such as in their use of sanctioning powers, the extent to which frontline staff felt they are advocates for their clients' rights and minor differences in the way firms prioritised different types of clients were also found.

By 2008, the Australian employment sector had changed substantially. The process used to 'roll over' contracts based upon the Star Ratings meant that the 223 agencies operating in 1999 had been reduced to $113,{ }^{11}$ all of which were privately run. The survey results also indicate that the levels of diversity that had been observed in the sector in 1998 had been largely lost. An analysis of the 2008 data shows very little difference in the responses offered by frontline staff working for different types of agencies. In Table 5, the data presented above in Table 2 for 2008 are presented again, this time by agency type. The results are remarkably similar across agencies. 
In response to the statement: 'when it comes to day-to-day work I am free to decide for myself what I will do with each jobseeker', of those who 'strongly agreed', 18.5 per cent work in for-profit agencies and 18.1 per cent work in not-for-profit agencies. The difference between the responses given by staff from different agencies to that question is not statistically significant $(\mathrm{p}=0.3)$. Likewise, responses to the statements 'when I come across something not covered by the procedural guide, I refer to my supervisor' and 'our computer system tells me what steps to take with jobseekers and when to take them' were not statistically significant for different types of agencies $(p=0.4$ for the former and $p=0.7$ for the later) (see Table 5). However, there is a statistically significant difference between agencies for the statement: 'my supervisor knows a lot about the work I do day-to-day' ( $p=$ 0.027), with 39.8 per cent of frontline staff working in for- profit agencies strongly agreeing, compared to 30.5 per cent in the not-for-profit sector.

Table 5: Entrepreneurialism in the workplace by agency type (2008 only)

\begin{tabular}{|c|c|c|c|c|c|}
\hline & $\begin{array}{l}\text { Strongly } \\
\text { agree }\end{array}$ & Agree & Neither & Disagree & $\begin{array}{l}\text { Strongly } \\
\text { disagree }\end{array}$ \\
\hline \multicolumn{6}{|c|}{$\begin{array}{l}\text { 'When it comes to day-to-day work I am free to decide for myself what I will do with eacl } \\
\text { jobseeker.' }\end{array}$} \\
\hline For profit & $45(18.5 \%)$ & $100(41.2 \%)$ & $46(18.9 \%)$ & $44(18.1 \$)$ & $8(3.3 \%)$ \\
\hline $\begin{array}{l}\text { Not-for- } \\
\text { profit }\end{array}$ & $115(18.1 \%)$ & $289(45.6 \%)$ & $85(13.4 \%)$ & $117(18.5 \%)$ & $28(4.4 \%)$ \\
\hline Total & $160(18.3 \%)$ & $389(44.4 \%)$ & $131(14.9 \%)$ & $161(18.4 \%)$ & $36(4.1 \%)$ \\
\hline \multicolumn{6}{|c|}{ Chi-squared $=4.931 ; p=0.294)$} \\
\hline \multicolumn{6}{|c|}{ 'My supervisor knows a lot about the work I do day-to-day.' } \\
\hline For-profit & $96(39.8 \%)$ & $110(45.6 \%)$ & $11(4.6 \%)$ & $18(7.5 \%)$ & $6(2.5 \%)$ \\
\hline $\begin{array}{l}\text { Not-for- } \\
\text { profit }\end{array}$ & $191(30.5 \%)$ & $312(49.8 \%)$ & $55(8.8 \%)$ & $42(6.7 \%)$ & $27(4.3 \%)$ \\
\hline Total & $287(33.1 \%)$ & $422(48.6 \%)$ & $66(7.6 \%)$ & $60(6.9 \%)$ & $33(3.8 \%)$ \\
\hline \multicolumn{6}{|c|}{ Chi-squared $=10.95 ; \mathrm{p}=0.027$} \\
\hline \multicolumn{6}{|c|}{$\begin{array}{l}\text { 'When I come across something not covered by the procedural guide, I refer it to my } \\
\text { supervisor.' }\end{array}$} \\
\hline For-profit & $95(39.4 \%)$ & $126(52.3 \%)$ & $12(5.0 \%)$ & $7(2.9 \%)$ & $1(0.4 \%)$ \\
\hline $\begin{array}{l}\text { Not-for- } \\
\text { profit }\end{array}$ & $202(32.3 \%)$ & $367(58.6 \%)$ & $33(5.3 \%)$ & $21(3.4 \%)$ & $3(0.5 \%)$ \\
\hline Total & $297(34.3 \%$ & $493(56.9 \%)$ & $45(5.2 \%)$ & $28(3.2 \%)$ & $4(0.5 \%)$ \\
\hline \multicolumn{6}{|c|}{ Chi-squared $=3.982 ; p=0.408$} \\
\hline \multicolumn{6}{|c|}{ 'Our computer system tells me what steps to take with jobseekers and when to take them.' } \\
\hline
\end{tabular}




\begin{tabular}{|l|l|l|l|l|l|}
\hline For-profit & $10(4.1 \%)$ & $99(41.1 \%)$ & $64(26.6 \%)$ & $53(22.0 \%)$ & $15(6.2 \%)$ \\
\hline $\begin{array}{l}\text { Not-for- } \\
\text { profit }\end{array}$ & $34(5.4 \%)$ & $267(42.7 \%)$ & $141(22.5 \%)$ & $149(23.8 \%)$ & $35(5.6 \%)$ \\
\hline Total & $44(5.1 \%)$ & $366(42.2 \%)$ & $205(23.6 \%)$ & $202(23.3 \%)$ & $50(5.8 \%)$ \\
\hline
\end{tabular}

Overall, the 2008 survey data show few statistically significant differences between for-profit and not-for-profit agencies. Table 6 is a sample of thirty-two survey questions asked in 2008. They have been tested for statistically significant differences between agencies. A difference was found for only seven questions, or 21.9 per cent of the time. This suggests that the trend in the sector towards standardisation discussed above is not isolated to a particular type of agency. These results also suggest that, while there was an absence of frontline flexibility within agencies by 2008, there was also a lack of flexibility between agencies by the end of Job Network. In the final section, we consider what might have caused the increased levels of standardisation observed in the changes over this ten-year period.

\section{Discussion - explaining standardisation in the Australian employment sector}

Writing in 1999, as the post-Fordist welfare state was starting to take shape, Considine (1999) hypothesised that the new, emergent welfare system would be defined by two characteristics. On the macro level, traditional bureaucracies would be broken down in favour of a system whereby 'empowered local officials' would work within multi-agency systems. On a micro level, there would be a 'transformation of work within this field from a service system based upon rules, procedures and universal categories of entitlement, to one emphasising entrepreneurial and discretionary treatments for individual clients exercised at a local level of programme definition' (Considine, 1999: 187). However, contrary to these expectations, and those of many other theorists and advocates of the post-Fordist welfare state and NPM, private agencies contracted to deliver public services do not generate different service delivery styles, their frontline staff do not exercise significant discretion in tailoring services and the trend over time is towards high levels of standardisation for both staff and jobseekers. What this natural experiment in radical system change has shown is that the contracting- out of social services does not produce a new industry of service innovators with new approaches to working with clients, but a 'herd' of profit maximisers who are 
highly responsive to threats to their viability and who embrace standardisation of services as a way to minimise risks. 
Table 6: Statistical significance by agency type (2008 only) (X denotes a statistically

significant difference)

\begin{tabular}{|c|c|}
\hline Survey question & $\begin{array}{l}\text { For-profit } \\
\text { versus not-for- } \\
\text { profit agencies }\end{array}$ \\
\hline Special responsibility for a particular group & $\mathrm{X}$ \\
\hline \multicolumn{2}{|l|}{ Caseload size } \\
\hline Number of clients seen per day & $\mathrm{X}$ \\
\hline \multicolumn{2}{|l|}{ Use of assessment results in determining how to work with jobseekers } \\
\hline \multicolumn{2}{|l|}{ The influence of special funds } \\
\hline \multicolumn{2}{|l|}{ Emphasis on getting a quick outcome } \\
\hline \multicolumn{2}{|l|}{ Time spent in direct contact with jobseekers } \\
\hline \multicolumn{2}{|l|}{ Time spent working with other service providers } \\
\hline Time spent working with employers & $\mathrm{X}$ \\
\hline Time working on contract compliance and administration & $\mathrm{X}$ \\
\hline \multicolumn{2}{|l|}{ Level of contact with other offices in the same organisation } \\
\hline \multicolumn{2}{|l|}{ Level of contact with government departments } \\
\hline \multicolumn{2}{|l|}{ Level of contact with local government } \\
\hline \multicolumn{2}{|l|}{ Level of contact with welfare agencies } \\
\hline Level of contact with employers & $\mathrm{X}$ \\
\hline \multicolumn{2}{|l|}{ Level of contact with training providers } \\
\hline \multicolumn{2}{|l|}{ Level of contact with another employment agency } \\
\hline \multicolumn{2}{|l|}{ Level of contact with local service clubs } \\
\hline \multicolumn{2}{|l|}{ Level of contact with schools and universities } \\
\hline \multicolumn{2}{|l|}{ Level of contact with the local media } \\
\hline \multicolumn{2}{|l|}{ Information sources: own organisation } \\
\hline Information sources: government departments & $\mathrm{X}$ \\
\hline \multicolumn{2}{|l|}{ Information sources: own experience } \\
\hline \multicolumn{2}{|l|}{ Information sources: newspapers } \\
\hline \multicolumn{2}{|l|}{ Information sources: employers } \\
\hline \multicolumn{2}{|l|}{ Information sources: another organisation } \\
\hline \multicolumn{2}{|l|}{ The best service goes to the most capable jobseekers } \\
\hline $\begin{array}{l}\text { Agency goal: to help jobseekers get a job quickly OR raise education } \\
\text { levels }\end{array}$ & $\mathrm{X}$ \\
\hline \multicolumn{2}{|l|}{ Use of standard program rules and regulations } \\
\hline \multicolumn{2}{|l|}{ Leeway in deciding on programs for jobseekers } \\
\hline \multicolumn{2}{|l|}{ Case management is about following the rules } \\
\hline My job is routine & \\
\hline
\end{tabular}


This unexpected result is not peculiar to Australia. Rik Van Berkel argues that formal policy changes create 'a pressure to reform operational policies' (Van Berkel, 2009: 19).

Specifically, he argues that policy changes designed to 'activate' jobseekers, and create quasi-markets within the UK, German, Danish and Dutch employment sectors have had an impact on how jobseekers experience the employment system at the frontline (Van Berkel, 2009). He further argues that "contrary to the expectations of those who predicted the end of the old public administration, procedures and regulations remain of importance' (Van Berkel, 2009: 31). Likewise, Bredgaard and Larsen's analysis of the Australian and Dutch contracted employment systems concludes that:

[t]he general impression is that, in spite of the freedom to choose their own methods, providers hardly ever come up with innovative solutions. Rather than developing new methods and innovating services, the providers' primary focus is on survival, and they are not willing to take any risks unless the outcome is considered certain. (Bredgaard and Larsen, 2008: 345)

Returning to our original Australian survey data, how are we to explain the advent of increased standardisation in the Australian context? Since we have only these data concerning frontline services and we lack comparable data on managerial attitudes and imperatives over this period, our answer must be somewhat partial. But the explanation that best fits these trends is that a coincidence of pressures by the contractor and the agency managers have produced an outcome that helps them manage risks, even if it is doubtful that this honours their key public policy commitment to tailoring or individualisation of services.

DEEWR, the purchaser of Australian employment services, imposed significant changes on the market as Job Network matured. Importantly, they required contracted providers to enter into more detailed contracts, which had the dual effect of reducing flexibility and eroding diversity between agencies. One of the reasons for this was that firms used the flexibility they enjoyed under early contracts to undermine key public policy goals in the interests of increasing their profits. The purchaser then became increasingly focused on monitoring agencies to ensure contract compliance. Marston and McDonald (2008: 258) argue that the government maintained control over Job Network using a variety of means such as 'the use of key performance indicators embedded in contracts, through a comparative evaluative system known as the "star ratings", and through the application of an IT-based information 
system that allows departmental officers to review the activities of front-line operatives'. Increased oversight on the part of the purchaser resulted in agencies shifting some of their resources away from providing one-on-one assistance to jobseekers, and towards local administration. Contract compliance scrutiny, and 'recovery' activity, whereby DEEWR would require non-compliant agencies to refund fees, engendered fear of non-compliance in agencies and individuals. The use of the Star Ratings to reallocate business also gave the purchaser an effective weapon to punish the non-compliant. The result was far greater effort to reduce risk, often through new forms of service standardisation.

When the Howard Coalition Government lost office in December 2007, the newly elected Rudd Labor Government sought feedback on how Australia's contracted-out employment system has been working. They received over 260 submissions from a range of employment sector stakeholders, airing their grievances and proposing avenues for reform (Commonwealth of Australia, 2008: 5). Many of the submissions addressed the issues of inflexibility and bureaucratic contract requirements. For example, the representative body for all Australian employment services providers, the National Employment Services Association's (NESA) objected to ‘increased specificity and prescription of service requirements' (cited in Commonwealth of Australia, 2008: 6), while Jobs Australia, which represents not-for-profit agencies, submitted to the inquiry that '[o]ver the last 10 years program guidelines have become more prescriptive and rigid as the degree of micromanagement has grown and innovation has been stifled. Contract management has increasingly focused on the fine detail of service providers' processes in contrast to the original premise of relying on the skills and innovation of the private and community sectors' (cited in Commonwealth of Australia, 2008: 8). Not-for-profit organisation, and former Job Network service provider, the Brotherhood of St Lawrence, argued that 'fragmentation and complexity of the overall system, undermine[d] the confidence of providers, and increase[d] the expenditure on program monitoring and compliance' (cited in Commonwealth of Australia, 2008: 7), while a submission from private employment services agency Sarina Russo argued that ' $[u] p$ to 60 per cent of consultants' time is spent on administration' (cited in Commonwealth of Australia, 2008: 7).

In response to those submissions, the Rudd Government concluded that: 
Employment services need the flexibility and resources to help the most disadvantaged job seekers to acquire the skills that they and employers need. These are the clear messages from job seekers, employers and employment service providers who have contributed to the Government's review of employment services. (Commonwealth of Australia, 2008: 2)

Yet despite the industry's strong focus on the impact that complex contracts, and departmental auditing, had on the sector, another trend may help account for the standardisation observed in the 2008 data. It is possible that employment agency managers chose to encourage standardisation among their frontline staff because it suited their own objectives.

In 2001, the Australian Productivity Commission undertook an independent review of Job Network. In the report that followed, the Commission discussed two problems widely associated with the early years of Job Network: 'creaming' and 'parking' (Considine, 2001). 'Creaming' was said to be a problem in cases where 'there is any discretion in taking or subsequently excluding clients', the result being that private providers preferred to focus their energy on 'those job seekers most likely to achieve payable outcomes' (Commonwealth of Australia, 2002: 80). 'Parking' was said to occur when providers 'have incentives to manipulate the system by "parking" (providing little assistance to) clients with low employment probabilities, creating temporary artificial jobs that maximise placement payments, and rotating people through them' (Commonwealth of Australia, 2002: 80). The practice of parking and creaming meant that the most disadvantaged jobseekers were unlikely to receive a suitable level of job-search assistance as private employment providers found it economically beneficial to focus their energy on jobseekers who afforded them a reasonable prospect of profit generation (or larger profit generation). Creaming and parking were significant political issues in Australia in the late 1990s and early 2000s. This is evidenced by the Government's decision to refer the matter to the Australian Productivity Commission.

The suggestion that some employment services providers were not providing all jobseekers with a satisfactory level of service cast a shadow over the entire private employment sector. It seems possible that one of the ways agencies responded to allegations of under-servicing was by choosing to standardise certain minimum internal operating procedures. Voluntary standardisation was also a means by which managers of private employment agencies could 
mitigate other risks too, such as frontline staff spending time on strategies that did not result in a job placement.

To explore this issue further, interviewees were asked about the sources of increased routinisation and administration in the Australian employment sector. Most interviewees attributed the largest portion of the blame to DEEWR and one might expect that this would be the norm in contracted systems. However, there was some suggestion that agencies themselves were also implicated in the trend. For example, 'Cameron', who had worked in the sector for five years, and at the time of the interview was working for a not-for-profit agency, argued that:

because DEEWR would say one thing and then six months later do another thing, or ask them [the contracted agency] to justify it, organisations became a little bit more scared and they put too much administration in place, so it wasn't actually the contract asking for such administration, it was more the organisation. So there was paperwork, paperwork for everything that you needed to do.

And:

I worked for three different organisations, and the administration from DEEWR's perspective never changed. It changed from organisation to organisation, and really to be honest it is more about how compliance-focused they are. So I saw an administration rise in my current organisation because the people that were running the policy section were more compliance- focused, rather than performance-focused. So I didn't see a rise in administrative burdens from DEEWR's perspective, I saw it from an organisational perspective.

These comments indicate that there are two elements to contract compliance: what DEEWR is actually asking for; and what local management requires because they anticipate that DEEWR might ask for that thing at some point in the future.

'Amanda', who also worked for a not-for-profit agency, recounted that: 
I'd normally notice the change or the increase [in admin] when there had been an issue or a concern picked up or raised by DEEWR, that then there would be, from the organisation that you're working for, an increase in, structure in place to prevent the risk, the risk management of the things happening again.

Her comments reflect that when something happens in one agency it sends ripples throughout the sector, so that local management responds in other agencies without being directed to do so by DEEWR.

'Belinda', also working for a not-for-profit agency, when asked whether the kind of contract compliance work done goes over and above what DEEWR expects, responded:

To some degree, yes, but I think as a safeguard, and coming from working for government organisations, I think it's necessary when it comes to auditing purposes and compliance and policies and procedures. So to some degree, yes, the company does expect to a certain degree of a double up when it comes to the admin, but it's also been beneficial for us as a company to do that as well.

'Belinda' and 'Sonia' also agreed that rumours about DEEWR's view of what agencies should be doing spread, and agencies respond by trying to comply with what they imagine to be DEEWR's view.

These responses do not mean that the loss of innovation and creativity that occurred throughout the life of Job Network was not closely linked to government policy. Clearly, it was. However, it does suggest that contracted service providers also worked hard to reduce the risks of failure and in doing so also limited the scope for innovation, at least at the service delivery end of the system. Instead, the focus of change was in better business planning and system control, greater monitoring and what Michael Power (1994) would call an 'audit explosion'. A clear and logical path can be discerned in this combination of internal and external imperatives.

First, increases in departmental audit and intervention were arguably a reasonable response to a serious problem of under-servicing of some client groups and of fraud by private agencies willing to game the contracting system. Second, well-intentioned agencies faced high risk in 
being left in any system that allowed creaming and therefore began to reduce their exposure by 'herding' around more conservative service delivery norms. Third, agencies adopted even more strongly risk averse strategies once the DEEWR increased its capacity and willingness to pursue agencies for financial recoveries in cases where clients had been misallocated or where overcharging could be found. Hood et al. (2001: 31) identify important differences in the mix of actors in the regulation of risk and show that it is important to take account of 'how densely populated the regulatory space or policy community is by separate institutions'. We see this case as one in which an early form of under-regulation based on the comfortable conceit that each agency would operate its own 'black box' of innovative solutions, protected by commercial-in-confidence provisions in the contract, quickly turned to aggressive overregulation by both external and internal auditors. Job Network was then unable to harness the creative potential that advocates of NPM believed would flow from a quasi-market structure. In the case of the Australian employment sector, as privatisation increased, diversity decreased and herding around conservative practices became more rational than service delivery innovation, except of course the innovations associated with being better at the same strategy being adopted by one's competitors.

We suggest that during this ten-year period the government did not find a workable openground between ensuring an adequate level of service delivery for all clients of the service, and permitting a level of autonomy to agencies sufficient to allow them to bring creative solutions to bear on the problem of long-term unemployment. ${ }^{12}$ These trends were further driven by pricing pressures and a desire on the part of employment agencies to protect their contracts by engaging in conservative behaviours, which served to protect their public image against claims of impropriety, including under-servicing. Put simply, both the purchaser and the providers found reasons to prefer herding to more varied forms of service delivery.

These findings raise the important question: does social service contracting really have the capacity to de-bureaucratise core government social services in the interests of flexibility? The evidence of this study suggests that it does not unless a risk management regime crafted and made appropriate to the service delivery goal is in place. Tight and demanding regulation certainly succeeds in reducing error and providing a political response to fraud. Competition among contractors does promote efficiency. What neither quasi-markets nor tight regulation succeeded in doing on their own was to promote innovative solutions for the most vulnerable. For that, we conclude, a regulatory regime that rewards collective-action solutions among 
providers, employers and support services would be necessary, and, while some quasi-market elements of such a regime might well promote efficiency, based on the evidence so far, these on their own are unlikely to get the job done.

\section{Notes}

1. For a discussion of the erosion of large bureaucratic social services delivery structures, see for example Sabel (1994); Burrows and Loader (1994); Foster and Plowden (1996) and Considine and Painter (1997).

2. For the full results of the 2008 Australian survey, see Considine et al. (2009a). For the full results of the 2008 UK survey, see Considine et al. (2009b). For results from the 1996-99 survey (all countries), see Considine (2001).

3. The 2008 survey did not include New Zealand.

4. That figure is for the entire sample. A response rate for the 1999 Australian data only is not available.

5. For a detailed discussion concerning the establishment of Centrelink and Job Network, see Marston (2006). For a longer history of Australian employment assistance, see Marston and McDonald (2007).

6. A substantially revised version of the Star Ratings system was introduced when Job Search Australia was launched in July 2009.

7. For a discussion of the development of quasi-markets in employment services in the UK, Denmark, Germany and the Netherlands, see Van Berkel (2009).

8. For a discussion of this, see Van Berkel (2009) and Bifulco and Vitale (2006).

9. The expression 'that spend' refers to government money that can be used to fund training, or to purchase equipment required for a specific job.

10. In the 2008 version of the survey, survey respondents were able to select the response 'not relevant to my job' for the question 'how influential is your own judgement when deciding how to work with jobseekers'. That response was not available in the 1998 survey. To make the data as compatible as possible, the response 'not relevant to my job' was recoded as 'missing' for Table 4. 
11. The number of employment agencies in Australia was calculated using the Government's Star Ratings publication. The 2008 figure was based on the Star Ratings for September 2008. The 1999 figure was derived from the Star Ratings for October 1999.

12. For an early discussion of the challenges inherent in maintaining state control over private services, see Dunsire (1986), Mayntz (1993) and Kickert (1993). For a more recent discussion, see Van Berkel (2009). 


\section{References}

Access Economics and the Department of Employment and Workplace Relations (2002), Report to the Steering Committee: Star Ratings System Application to NEIS, available at http://www.workplace.gov.au/NR/rdonlyres/866393E5-F6B8-44EC-A2A95E8DD70340B8/0/neis_star_ratings_finalreport2.pdf, last accessed 22/12/10.

Bifulco, L and Vitale, T. (2006), 'Contracting for welfare services in Italy', Journal of Social Policy, 35: 495-513.

Bredgaard, T. and Larson, F. (2008), 'Quasi-markets in employment policy: do they deliver on promises?', Social Policy and Society, 7: 341-52.

Burrows, R. and Loader, B. (eds.) (1994), Towards a Post-Fordist Welfare State? London: Routledge.

Commonwealth of Australia (2002), Employment Services: An Active Participation Model, Discussion Paper, Canberra: Department of Employment and Workplace Relations.

Commonwealth of Australia (2008), The Future of Employment Services in Australia, Discussion Paper, available at http://www.ames.net.au/media/pdf/15_DEEWR_DiscussionPaper_May_08.pdf, last accessed $22 / 12 / 10$.

Considine, M. (1999), 'Markets, networks and the new welfare state: employment assistance reform in Australia', Journal of Social Policy, 28: 183-203.

Considine, M. (2001), Enterprising States: The Public Management of Welfare-to-Work, Cambridge: Cambridge University Press.

Considine, M. (2005), 'The reform that never ends: quasi-markets and employment services in Australia', in E. Sol and M. Westervel (eds.), Contractualism in Employment Services: A New Form of Welfare State Governance, The Hague: Kluwer Law International.

Considine, M., Lewis, J. and O'Sullivan, S. (2009a), 'Activating states: transforming the delivery of "welfare to work" services in Australia, the UK and the Netherlands - Australian report back to industry partners', Faculty of Arts, School of Social and Political Sciences, University of Melbourne, available at http://www.ssps.unimelb.edu.au/ research/projects/activating-states, last accessed 22/12/10.

Considine, M., Lewis, J. and O'Sullivan, S. (2009b), 'Activating states: transforming the delivery of "welfare to work" services in Australia, the UK and the Netherlands - UK report 
back to industry partners', Faculty of Arts, School of Social and Political Sciences, University of Melbourne, available at http://www.ssps.unimelb.edu.au/research/projects/activating- states, last accessed 22/12/10. Considine, M. and Painter, M. (eds.) (1997), Managerialism: The Great Debate, Melbourne: University of Melbourne Press.

Drucker, P. (1985), The Executive in Action, New York: HarperBusiness.

Dunsire, A. (1986), 'A cybernetic view of guidance, control and evaluation in the public sector', in F. Z. Kaufman, J. Majone and V. Ostrom (eds.), Guidance, Control and Evaluation in the Public Sector, New York: De Gruyter.

Finn, D. (1997), 'Labour's New Deal for the unemployed: making it work locally', Local Economy, 12: 247-58.

Foster, C. and Plowden, F. (1996), The State Under Stress: Can the Hollow State Be Good Government?, Buckingham: Open University Press.

Hammond, B. (1997), Foundations of Case Management, Australia: Deakin University. Hoggett, P. (1987), 'A farewell to mass production? Decentralisation as an emergent private and public sector paradigm', in P. Hoggett and R. Hambelton (eds.), Decentralisation and Democracy: Localising Public Services, Bristol: University of Bristol.

Hood, C., Henry, R. and Robert, B. (2001), The Government of Risk: Understanding Risk Regimes, Oxford: Oxford University Press

Keating, P. J. (1994), Working Nation: Policies and Programs (Government of Australia White Paper), Canberra: Australian Government Publishing Service.

Kemp, B. J. (1981), Annual Review of Rehabilitation, vol II, New York: Springer.

Kickert, W. (1993), 'Complexity, governance and dynamics: conceptual explorations of public network management', in Jan Kooiman (ed.), Modern Governance: New GovernmentSociety Interactions, London: Sage.

Lash, S. and Urry, J. (1987), The End of Organised Capitalism, Cambridge: Polity.

Marston, G. (2006), 'Employment services in an age of e-government', Information, Communication and Society, 9: 83-103.

Marston, G. and McDonald, C. (2007), 'Assessing the policy trajectory of welfare reform in Australia', Benefits, 15: 233-45. 
Marston, G. and McDonald, C. (2008), 'Feeling motivated yet? Long-term unemployed people's perspectives on the implementation of workfare in Australia', Australian Journal of Social Issues, 43: 255-69.

Mayntz, R. (1993), 'Governing failures and the problems of governability: some comments on a theoretical paradigm', in Jan Kooiman (ed.), Modern Governance: New GovernmentSociety Interactions, London: Sage.

Powell, W. W. (1990), 'Neither market nor hierarchy: network forms of organisation', Research in Organisational Behavior, 12: 295-336.

Power, M. (1994), The Audit Explosion, London: Demos.

Power, M. (1997), The Audit Society: Rituals of Verification, Oxford: Oxford University Press. Rogers, E. M. and Larsen, J. K. (1984), Silicon Valley Fever: Growth of High Technology Culture, New York: Basic Books.

Sabel, C. (1994), 'Flexible specialisation and the re-emergency of regional economies', in P. Hirst and J. Zeitlin (eds.) (1989), Reversing Industrial Decline? Industrial Structure and Policy in Britain and her Competitors, Oxford: Berg.

Van Berkel, R. (2009), 'The provision of income protection and activation services for the unemployed in 'active' welfare states: an international comparison', Journal of Social Policy, 39: $17-34$.

Williamson, O. (1975), Markets and Hierarchies, New York: Free Press. 